\title{
EFFECTS OF PROVINOLS ON CARDIODYNAMICS AND CORONARY FLOW IN ISOLATED RAT HEARTS
}

Ana Popovic ${ }^{1}$, Olga Pechanova ${ }^{2}$, Radoslava Rehakova ${ }^{2}$, Vladimir Zivkovic ${ }^{3}$, Ivan Srejovic ${ }^{3}$, Nevena Jeremic ${ }^{4}$, Jovana Jeremic ${ }^{4}$, Aleksandra Vranic ${ }^{4}$, Vladimir Jakovljevic ${ }^{3}$ ${ }^{1}$ General Hospital, Niksic, Montenegro

${ }^{2}$ Institute of Normal and Pathological Physiology, Slovak Academy of Sciences, Bratislava, Slovak Republic ${ }^{3}$ Department of Physiology, Faculty of Medical Sciences, University of Kragujevac, Kragujevac, Serbia

${ }^{4}$ Department of Pharmacy, Faculty of Medical Sciences, University of Kragujevac, Kragujevac, Serbia

\author{
EFEKTI PROVINOLA NA KARDIODINAMIKU I KORONARNI PROTOK \\ IZOLOVANIH SRCA PACOVA \\ Ana Popović ${ }^{1}$, Olga Pehanova ${ }^{2}$, Radoslava Rehakova ${ }^{2}$, Vladimir Živković3 ${ }^{3}$ Ivan Srejovićs ${ }^{3}$ Nevena Jeremić ${ }^{4}$ \\ Jovana Jeremić ${ }^{4}$, Aleksandra Vranić ${ }^{4}$, Vladimir Jakovljević ${ }^{3}$ \\ ${ }^{1}$ Opšta bolnica, Nikšić, Crna Gora \\ ${ }^{2}$ Institut za normalnu i patološku fiziologiju, Slovačka Akademija Nauka, Bratislava, Republika Slovačka \\ ${ }^{3}$ Katedra za Fiziologiju, Fakultet medicinskih nauka u Kragujevcu, Kragujevac, Srbija \\ ${ }^{4}$ Katedra za Farmaciju, Fakultet medicinskih nauka u Kragujevcu, Kragujevac, Srbija
}

Received / Primljen: 09.12.2015.

Accepted / Prihvaćen: 19.12.2015.

\begin{abstract}
Provinols are an alcohol-free extract of red wine that contains a wide range of polyphenols. Polyphenols are a group of chemical compounds found in diverse plants. Polyphenols are considered to protect against cardiovascular disease. Although some older epidemiological studies have indicated that the positive effects of red wine on heart disease can be attributed to the alcohol content alone, there is now powerful evidence that polyphenols present in red wine are responsible for these positive effects. The hearts of male Wistar albino rats $(n=36$, 12 in each experimental group, 10 weeks old, body mass 250 $\pm 30 \mathrm{~g}$ ) were excised and retrogradely perfused according to the Langendorff technique at a gradually increasing perfusion pressure (40-120 $\mathrm{cmH}_{2} \mathrm{O}$ ). Parameters of cardiac function ( $\mathrm{dp}$ ) dt max, dp/dt min, SLVP, DLVP, HR, CF) were measured after perfusion with three different concentrations of provinols $(5$ $\mu \mathrm{g} / \mathrm{ml}, 10 \mu \mathrm{g} / \mathrm{ml}$ and $50 \mu \mathrm{g} / \mathrm{ml})$. Administration of the highest dose $(50 \mathrm{\mu g} / \mathrm{ml})$ induced a significant increase in $\mathrm{dp} / \mathrm{dt}$ max, $d p / d t$ min, HR and CF compared with control conditions at $C P P=40 \mathrm{cmH}_{2} \mathrm{O}$, while an intermediate dose increased $\mathrm{dp} /$ $d t$ max at the same CPP. Generally viewed, the results of the present study suggest that provinols may have a beneficial effect on the intact myocardium and coronary circulation. These findings could constitute an important step in further investigation of these polyphenols under different representative experimental conditions in the heart, as well as providing a good basis for potential clinical studies in this field.
\end{abstract}

Keywords: Provinols, Isolated rat heart, Langendorff technique, Cardiodinamics, Coronary flow

\section{SAŽETAK}

Provinoli predstavljaju bezalkoholni ekstrakt crvenog vina koji sadrži širok spektar polifenola. Polifenoli su grupa hemijskih jedinjenja koje se nalaze u različitim vrstama biljaka. Smatra se da mogu da umanje rizik od nastanka kardiovaskularnih bolesti. Iako su ranije epidemiloške studije ukazale da pozitivni efekti crvenog vina na razvoj oboljenja srca potiču samo od alkoholne komponente, sada postoje čvrsta saznanja da su zapravo polifenoli zaslužni za ove efekte. Srca muških Wistar albino pacova $(n=36,12$ u svakoj grupi, 10 nedelja starosti, telesne mase $250 \pm 30 \mathrm{~g}$ ) su izolovana i retrogradno perfundovana prema modifikovanoj Langendorff-ovoj tehnici, uz postupno povećawe koronarnog perfuzionong pritiska (40-120 $\left.\mathrm{cmH}_{2} \mathrm{O}\right)$. Parametri srčane funkcije ( $d p / d t$ max, $d p / d t \min , S L V P, D L V P, H R, C F)$ su registrovani tokom perfuzije sa tri različite doze Provinola $(5 \mu \mathrm{g} / \mathrm{ml}, 10 \mu \mathrm{g} / \mathrm{ml}$ i $50 \mu \mathrm{g} / \mathrm{ml})$. Administracija najviše doze $(50 \mu \mathrm{g} / \mathrm{ml})$ je uzrokovala značajno povećanje vrednosti $\mathrm{dp} /$ $d t$ max, dp/dt min, HR $i$ CF u poređenju sa kontrolnim uslovima (pri $\mathrm{CPP}=40 \mathrm{cmH}_{2} \mathrm{O}$ ), dok je srednja doza povećala samo vrednosti dp/dt max na istom CPP. Generalno posmatrano, rezultati sadašnje studije sugerišu da Provinoli mogu da imaju pozitivne uticaje i na zdrav miokard $i$ koronarnu cirkulaciju. Ova saznanja mogu da budu važan korak u daljem ispitivanju ovih polifenola u različitim eksperimentalnim uslovima na srcu, kao i dobra osnova za potencijalne kliničke studije iz ove oblasti.

Ključne reči: Provinoli, Izolovano srce pacova, Langendorff-ova tehnika, Kardiodinamika, Koronarni protok
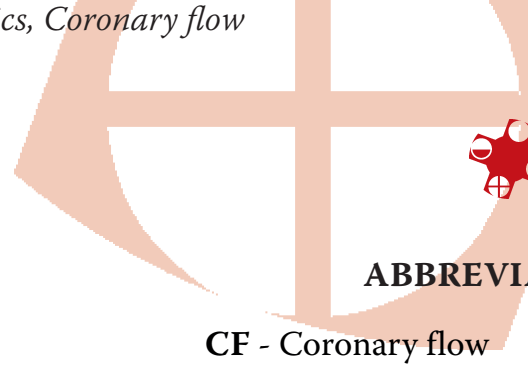

CF - Coronary flow

CPP - Coronary perfusion pressure

LDL - Low density lipoprotein

FDRW - Freeze-dried red wine VGSCs - Voltage-gated sodium channels 


\section{INTRODUCTION}

Provinols are an alcohol-free extract of red wine that contains wide range of polyphenols (1). These extracts have been studied in association with the discovery of the "French Paradox", describing a low incidence of cardiovascular disease in French people despite a diet rich in saturated fats. Researchers believe that this may be due to high consumption of wine in this country (2). Although some older epidemiological studies have indicated that the positive effects of red wine on heart disease can be attributed to the alcohol content alone $(3,4)$, there is powerful evidence that polyphenols present in red wine are responsible for these positive effects (5-7).

Polyphenols are a group of chemical compounds found in a vast variety of plants (8). Polyphenols are considered to protect against cardiovascular disease $(9,10)$ and some cancers (11). Additionally, a large number of studies have demonstrated strong antioxidant properties and inhibition of the peroxidation of polyunsaturated fatty acids (12). These properties of polyphenols can be explained by low density lipoprotein and platelet aggregation (13). Previous studies on red wine polyphenols have shown positive effects on the oxidation of LDL-cholesterol (14), arterial hypertension (13) and vasorelaxation (15). Based on these properties, diets supplemented with foods containing polyphenols might also protect various tissues against heart injury.

Reports describing the oral administration of red wine polyphenolic compounds, including provinols, indicate their ability to decrease blood pressure in normotensive rats (16). In addition, an accelerated decrease in blood pressure and improvement of structural and functional cardiovascular characteristics occur as a consequence of chronic inhibition of nitric oxide (NO) synthesis (17). All of these effects of provinols are associated with a greater increase in NO synthase (NOS) activity in the left ventricle and aorta $(17,18)$. Because of the above properties, polyphenols may interfere with the atherogenesis process and/or the thrombotic phenomena associated with atherosclerosis, which could at least partially explain the beneficial effects of these substances.

On the other hand, there is a lack of data on the direct effects of red wine polyphenols on myocardial function, especially on coronary circulation in the intact heart. Thus, this study aimed to assess the direct and acute influence of provinols on cardiac function and coronary flow, using an isolated rat heart model.

\section{MATERIALS AND METHODS}

\section{Isolated heart preparation}

Hearts of male Wistar albino rats $(n=36,12$ in each experimental group, 10 weeks old, body mass $250 \pm 30 \mathrm{~g}$ ) were isolated and perfused via retrograde perfusion using the Langendorff technique (Langendorff apparatus, Experimetria Ltd, 1062 Budapest, Hungary). After brief ketamine/xylazine narcosis, the animals were euthanized via cervical dislocation
(Schedule 1 of the Animals/Scientific procedures, Act 1986, United Kingdom) and premedicated with heparin. This was followed by immediate thoracotomy and sudden cardiac arrest induced by superfusion with ice-cold isotonic saline. The hearts were rapidly excised, and the aortas were cannulated and retrogradely perfused at a pressure in the range of 40 to $120 \mathrm{cmH}_{2} \mathrm{O}$. They were subsequently perfused in a reverse fashion via the aorta with Krebs-Henseleit solution (nutrientrich, oxygenated solution). The composition of the nonrecirculating Krebs-Henseleit perfusate was as follows $(\mathrm{mM} / \mathrm{L})$ : $\mathrm{NaCl} 118, \mathrm{KCI} 4.7, \mathrm{CaCl}_{2} \cdot 2 \mathrm{H}_{2} \mathrm{O} 2.5, \mathrm{MgSO}_{4} \cdot 7 \mathrm{H}_{2} \mathrm{O} 1.7, \mathrm{NaH}-$ $\mathrm{CO}_{3} 25, \mathrm{KH}_{2} \mathrm{PO}_{4} 1.2$, and glucose 11, equilibrated with $95 \%$ $\mathrm{O}_{2}$ plus $5 \% \mathrm{CO}_{2}$ and warmed to $37^{\circ} \mathrm{C}(\mathrm{pH}$ 7.4).

All experimental procedures were performed in accordance with prescribed legislation (EU Directive for the Protection of Vertebrate Animals used for Experimental and Other Scientific Purposes 86/609/EES) and the principles of ethics.

\section{Physiological Assay and Experimental Protocol}

After successful heart perfusion at a CPP of $60 \mathrm{cmH}_{2} \mathrm{O}$, a $30 \mathrm{~min}$ period was allowed for stabilisation of the preparation. To test coronary vascular reactivity, all hearts were challenged via short-term occlusion (5-30 s), followed by a bolus injection of $5 \mathrm{mM} / \mathrm{L}$ adenosine $(60 \mu \mathrm{L}$ at a flow rate of $10 \mathrm{~mL} / \mathrm{min}$ to elicit maximum coronary flow (CF)) during the stabilisation period. The hearts were discarded if the flow did not increase by $100 \%$ over the control value for both tests (approximately 25\% of hearts). When the flow was considered stable (three measurements of the same values), coronary effluent samples were collected.

After control sets of experiments (control conditions), hearts were perfused with

(1) provinols at a dose $5 \mu \mathrm{g} / \mathrm{ml}$

(2) provinols at a dose $10 \mu \mathrm{g} / \mathrm{ml}$

(3) provinols at a dose $50 \mu \mathrm{g} / \mathrm{ml}$.

After establishing a stable heart rate, removal of the left atrium and rupture of the mitral valve allowed a sensor to be inserted (transducer BS4 73-0184, Experimetria Ltd., Budapest, Hungary) in the left ventricle for direct and continuous monitoring of the following parameters of left ventricular function:

1. dp/dt max - maximum rate of pressure development in the left ventricle,

2. $\mathrm{dp} / \mathrm{dt}$ min - minimum rate of pressure development in the left ventricle,

3. SLVP - systolic pressure of the left ventricle,

4. DLVP - diastolic pressure of the left ventricle,

5. HR - heart rate.

Coronary flow was measured using flowmetry. The substances tested within a series of acute experiments were administered via continuous perfusion under changing perfusion pressures, starting from a pressure of $60 \mathrm{cmH}_{2} \mathrm{O}$, followed by 80 $\mathrm{cmH}_{2} \mathrm{O}, 100 \mathrm{cmH}_{2} \mathrm{O}$, and $120 \mathrm{cmH}_{2} \mathrm{O}$, and finally, $40 \mathrm{cmH}_{2} \mathrm{O}$ at end of the experiment. For each perfusion pressure, functional parameters of the left ventricle were registered. 

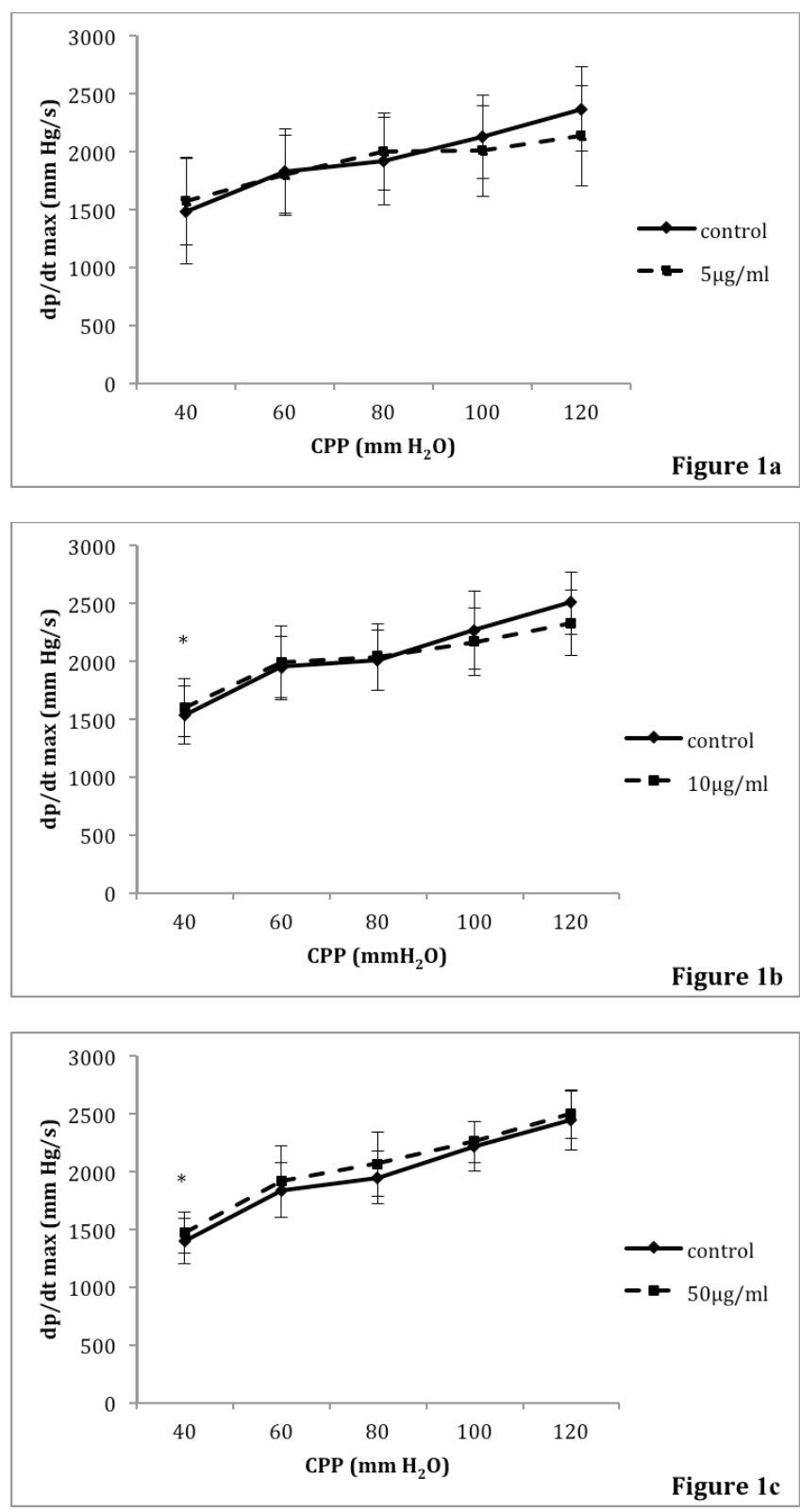

Figure 1a-c. The effects of $5 \mu \mathrm{g} / \mathrm{ml}$ provinol (1a), $10 \mu \mathrm{g} / \mathrm{ml}$ provinol (1b) and $50 \mu \mathrm{g} / \mathrm{ml}$ provinol (1c) on dp/dt max. The values represent $\mathrm{X} \pm \mathrm{SE}$; " $\mathrm{p}<0.05,{ }^{* * *} \mathrm{p}<0.01$

In the experimental work, the rules regarding the welfare of laboratory animals and the rules for the use of experimental animals of the Faculty of Medical Sciences, University of Kragujevac, were respected, which are compliant with the European Directive in this area.

\section{Drug}

Provinols were purchased from the French company VITIMED Groupe UDM Distillerie du Vivarais (Route de Ruoms BP 47, 07150 Vallon Pont d'Arc France).

\section{Statistics}

The statistical analysis of the experimental data included the following basic descriptive statistics: the mean value $(\mathrm{X}) \pm$ the standard deviation (SD). The following statistical
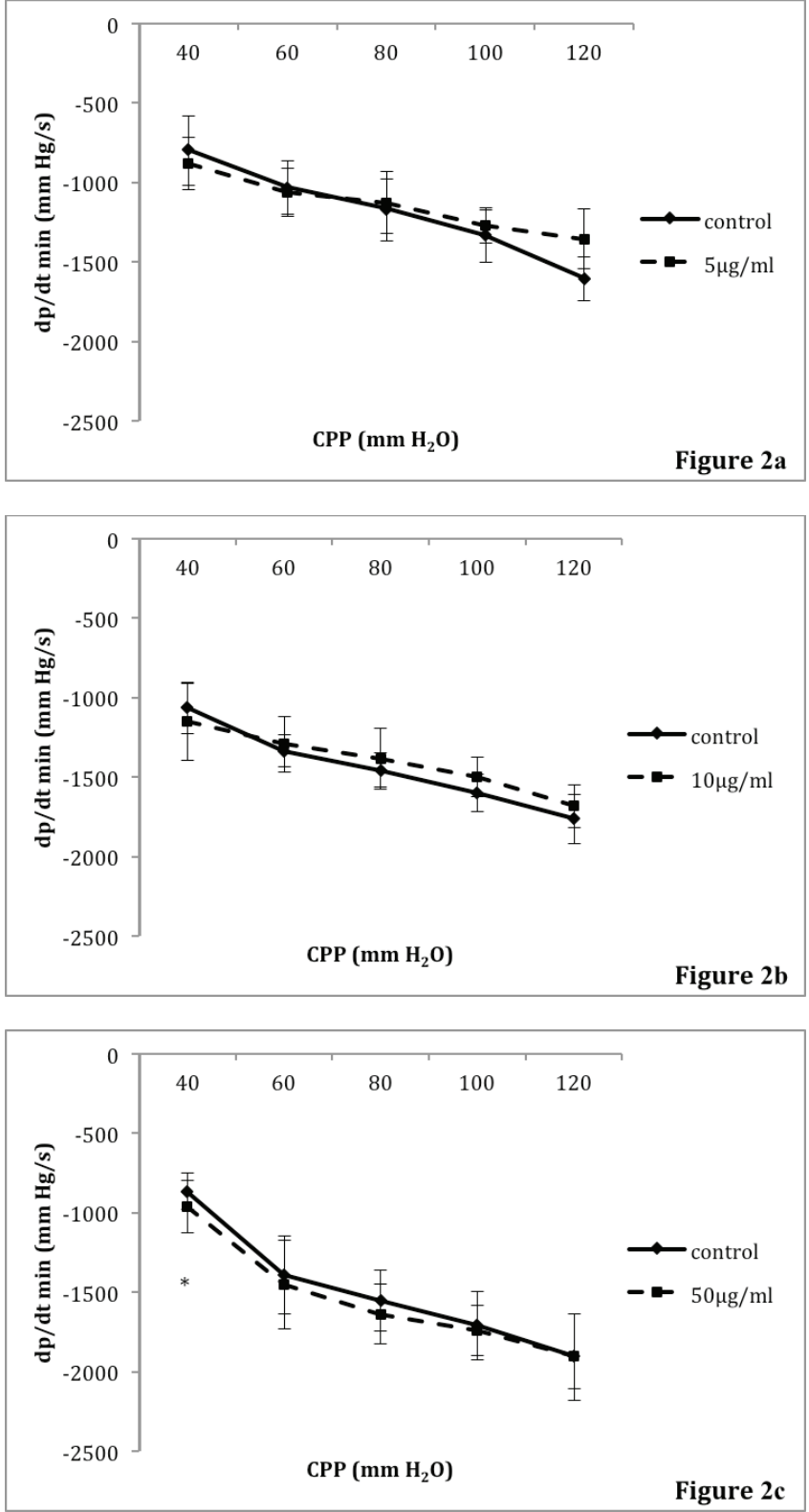

Figure 2a-c. The effects of $5 \mu \mathrm{g} / \mathrm{ml}$ provinol (2a), $10 \mu \mathrm{g} / \mathrm{ml}$ provinol (2b) and $50 \mu \mathrm{g} / \mathrm{ml}$ provinol $(2 \mathrm{c})$ on $\mathrm{dp} / \mathrm{dt}$ min. The values represent $\mathrm{X} \pm \mathrm{SE}$; " $\mathrm{p}<0.05,{ }^{* * \mathrm{p}}<0.01$

test was used to test the statistical significance of the results and to confirm the hypothesis: paired-samples $\mathrm{T}$ test. A database analysis of the results was performed using the software package SPSS 20th (SPSS Inc., Chicago, IL, USA). $P$ values lower than $0.05(\mathrm{p}<0.05)$ were considered to be significant, while $P$ values lower than $0.01(\mathrm{p}<0.01)$ were considered to be highly significant.

\section{RESULTS}

Maximum rate of pressure development in the left ventricle $(\mathrm{dp} / \mathrm{dt} \max )$

Parameters related to contractile force and systolic performance showed no significant changes between the control and 

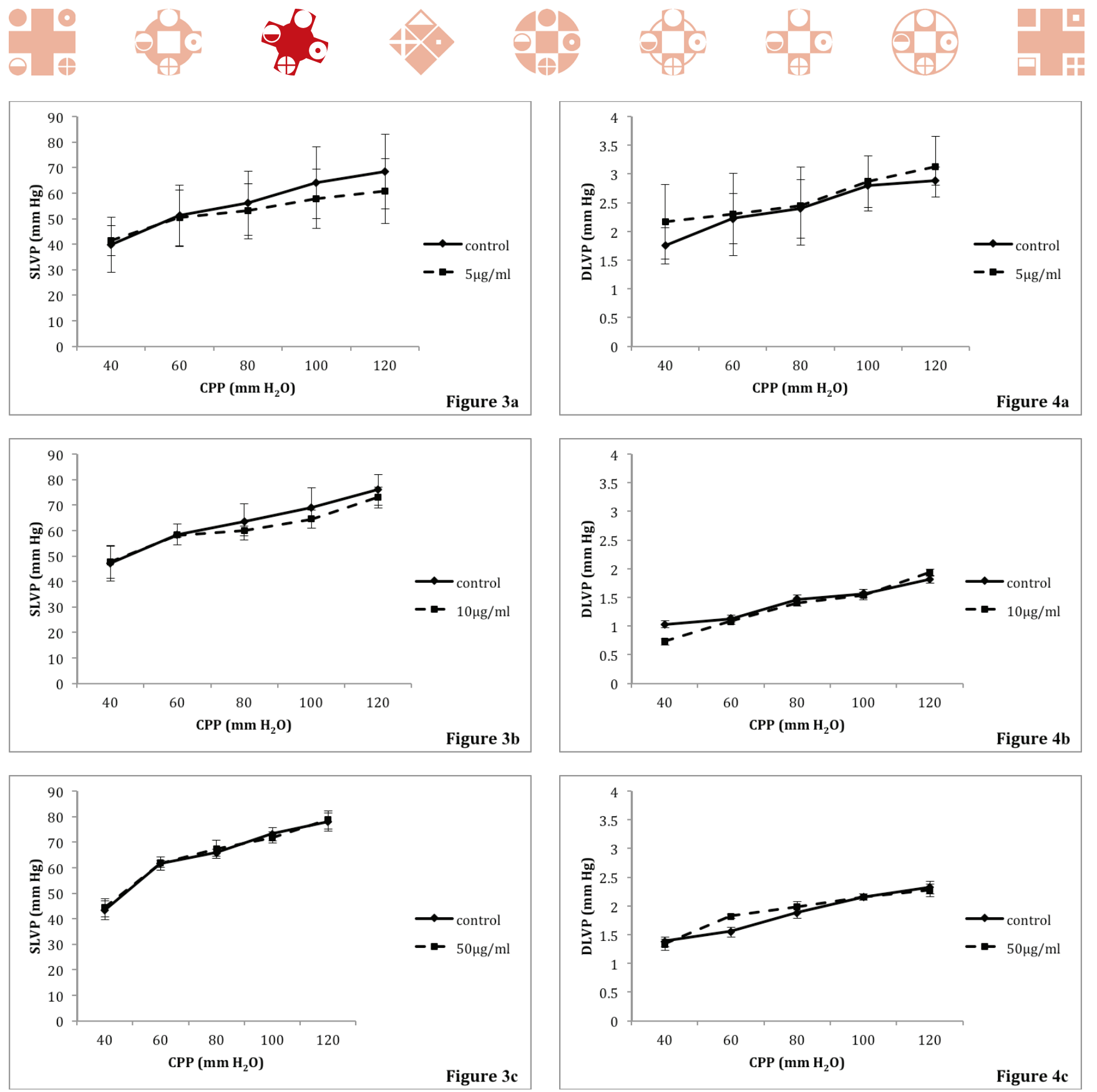

Figure 3a-c. The effects of $5 \mu \mathrm{g} / \mathrm{ml}$ provinol (3a), $10 \mu \mathrm{g} / \mathrm{ml}$ provinol (3b) and $50 \mu \mathrm{g} / \mathrm{ml}$ provinol (3c) on SLVP. The values represent $\mathrm{X} \pm \mathrm{SE}$; " $\mathrm{p}<0.05,{ }^{* * \mathrm{p}}<0.01$

the lowest dose of provinols $(5 \mu \mathrm{g} / \mathrm{ml})$ when compared at the same CPP over the entire CPP range ( $>0.05)$ (Fig 1a). Administration of the intermediate $(10 \mu \mathrm{g} / \mathrm{ml})$ and highest $(50 \mu \mathrm{g} / \mathrm{ml})$ doses induced a significant increase in $\mathrm{dp} / \mathrm{dt}$ max compared with the control conditions at $\mathrm{CPP}=40 \mathrm{cmH}_{2} \mathrm{O}(\mathrm{p}<0.05)$ (Figs 1b, 1c).

Minimum rate of pressure development in the left ventricle (dp/dt min)

There were no statistically significant changes in the values of parameters describing the lusitropic effect (diastolic function) during the application of $5 \mu \mathrm{g} / \mathrm{ml}$ provinols or $10 \mu \mathrm{g} / \mathrm{ml}$ provinols over the entire CPP range $(\mathrm{p}>0.05)$ (Figs 2a, 2b). Perfusion with the highest dose of provinols $(50 \mu \mathrm{g} / \mathrm{ml})$ induced a significant increase in $\mathrm{dt} / \mathrm{dp} \mathrm{min}$ at $\mathrm{CPP}=40 \mathrm{cmH}_{2} \mathrm{O}(\mathrm{p}<0.05)$ (Figure 2c).

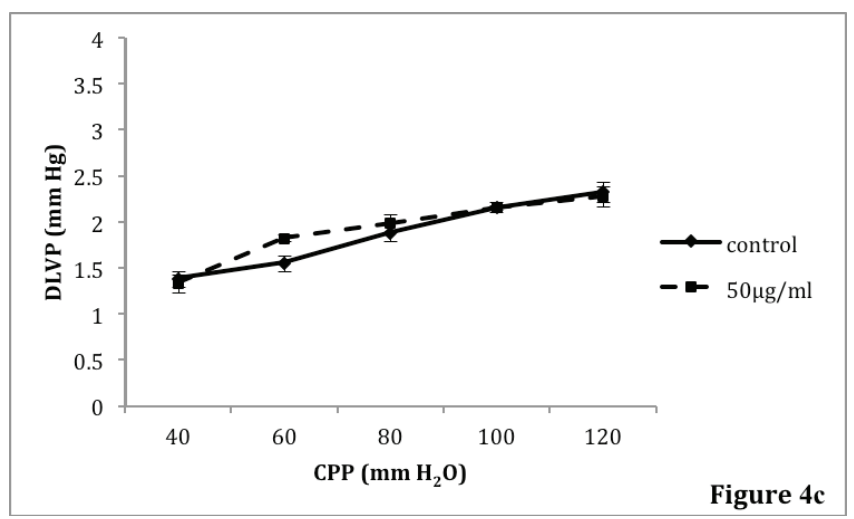

Figure 4a-c. The effects of $5 \mu \mathrm{g} / \mathrm{ml}$ provinol (4a), $10 \mu \mathrm{g} / \mathrm{ml}$ provinol (4b) and $50 \mu \mathrm{g} / \mathrm{ml}$ provinol (4c) on DLVP. The values represent $\mathrm{X} \pm \mathrm{SE}$; " $\mathrm{p}<0.05,{ }^{* * \mathrm{p}}<0.01$

\section{Systolic pressure of the left ventricle (SLVP)}

After the administration of provinols at doses of $5 \mu \mathrm{g} /$ $\mathrm{ml}, 10 \mu \mathrm{g} / \mathrm{ml}$ and $50 \mu \mathrm{g} / \mathrm{ml}$, we did not observe any statistically significant changes in systolic left ventricule pressure or parameters of myocardial function over the entire CPP range ( $\mathrm{p}>0.05)$ (Figs 3a, 3b, 3c).

\section{Diastolic pressure of the left ventricle (DLVP)}

Diastolic left ventricular pressure did not change significantly with an increase in CPP in the control or in all other groups $(\mathrm{p}>0.05)$. There was no significant difference between the control and any of the groups at any of the set CPPs $(\mathrm{p}>0.05)$ after the administration of all three doses of provinols $(5 \mu \mathrm{g} / \mathrm{ml}, 10 \mu \mathrm{g} / \mathrm{ml}$ and $50 \mu \mathrm{g} /$ ml) (Figs 4a, 4b, 4c). 

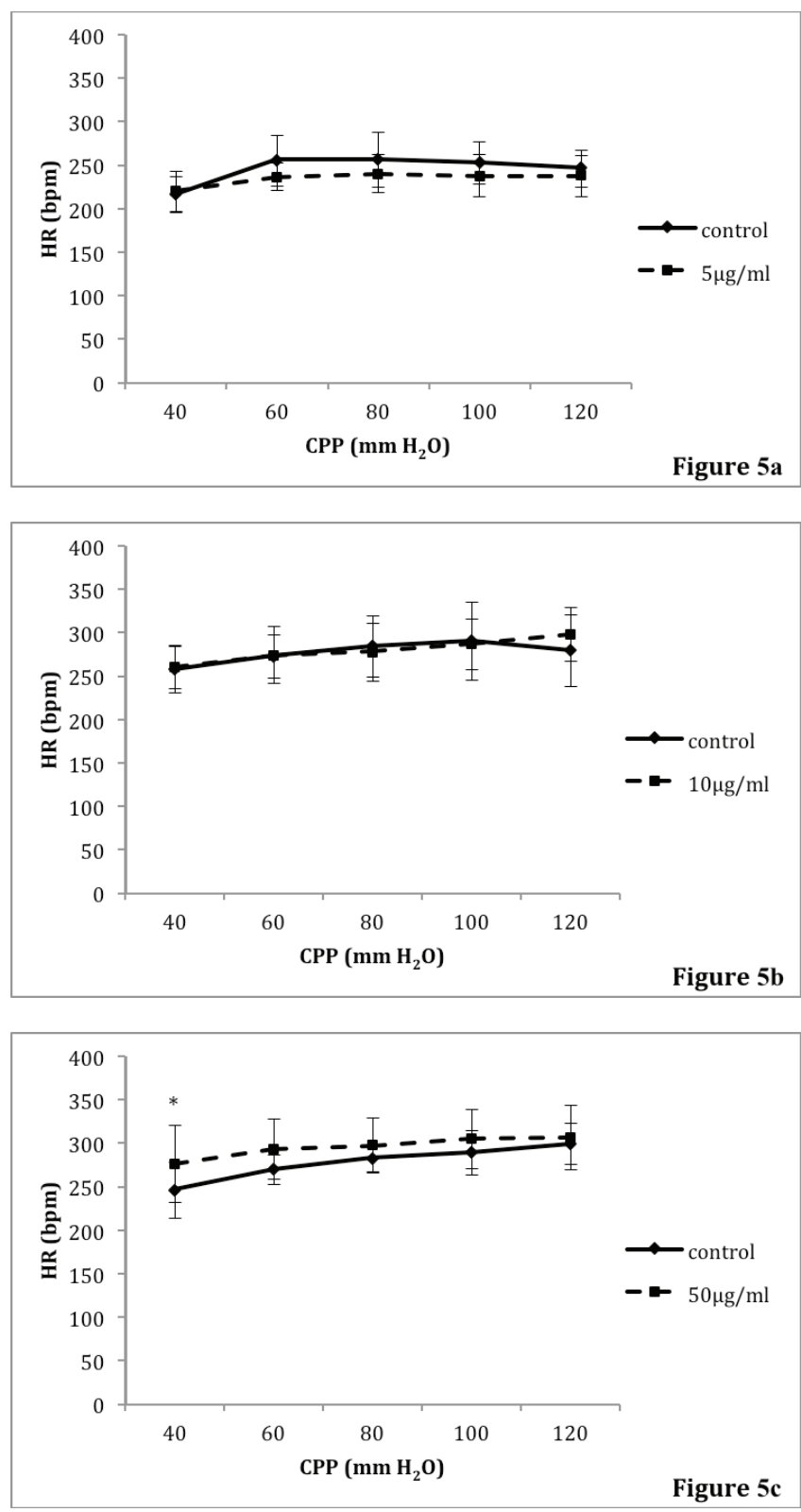

Figure 5a-c. The effects of $5 \mu \mathrm{g} / \mathrm{ml}$ provinol (5a), $10 \mu \mathrm{g} / \mathrm{ml}$ provinol (5b) and $50 \mu \mathrm{g} / \mathrm{ml}$ provinol (5c) on $\mathrm{HR}$. The values represent $\mathrm{X} \pm \mathrm{SE}$; " $\mathrm{p}<0.05$, *** $\mathrm{p}<0.01$

\section{Heart rate (HR)}

The heart rate did not change significantly under the lowest $(5 \mu \mathrm{g} / \mathrm{ml})$ and intermediate $(10 \mu \mathrm{g} / \mathrm{ml})$ doses of provinols with an increasing CPP ( $>>0.05)$ (Figs $5 \mathrm{a}, 5 \mathrm{~b})$. The administration of the highest dose of provinols $(50 \mu \mathrm{g} / \mathrm{ml})$ induced a significant increase in HR ( $>>0.05)$ compared with control conditions (Figure 5c).

\section{Coronary flow (CF)}

This parameter was significantly increased after the application of provinols at dose of $5 \mu \mathrm{g} / \mathrm{ml}(\mathrm{p}<0,05)$ at CPP $=40 \mathrm{cmH}_{2} \mathrm{O}$ (Figure 6a). After the administration of an intermediate dose of provinols $(10 \mu \mathrm{g} / \mathrm{ml})$, there was no significant difference detected over the entire CPP range ( $>0.05)$ (Figure 6b). Compared with the controls, the cor-
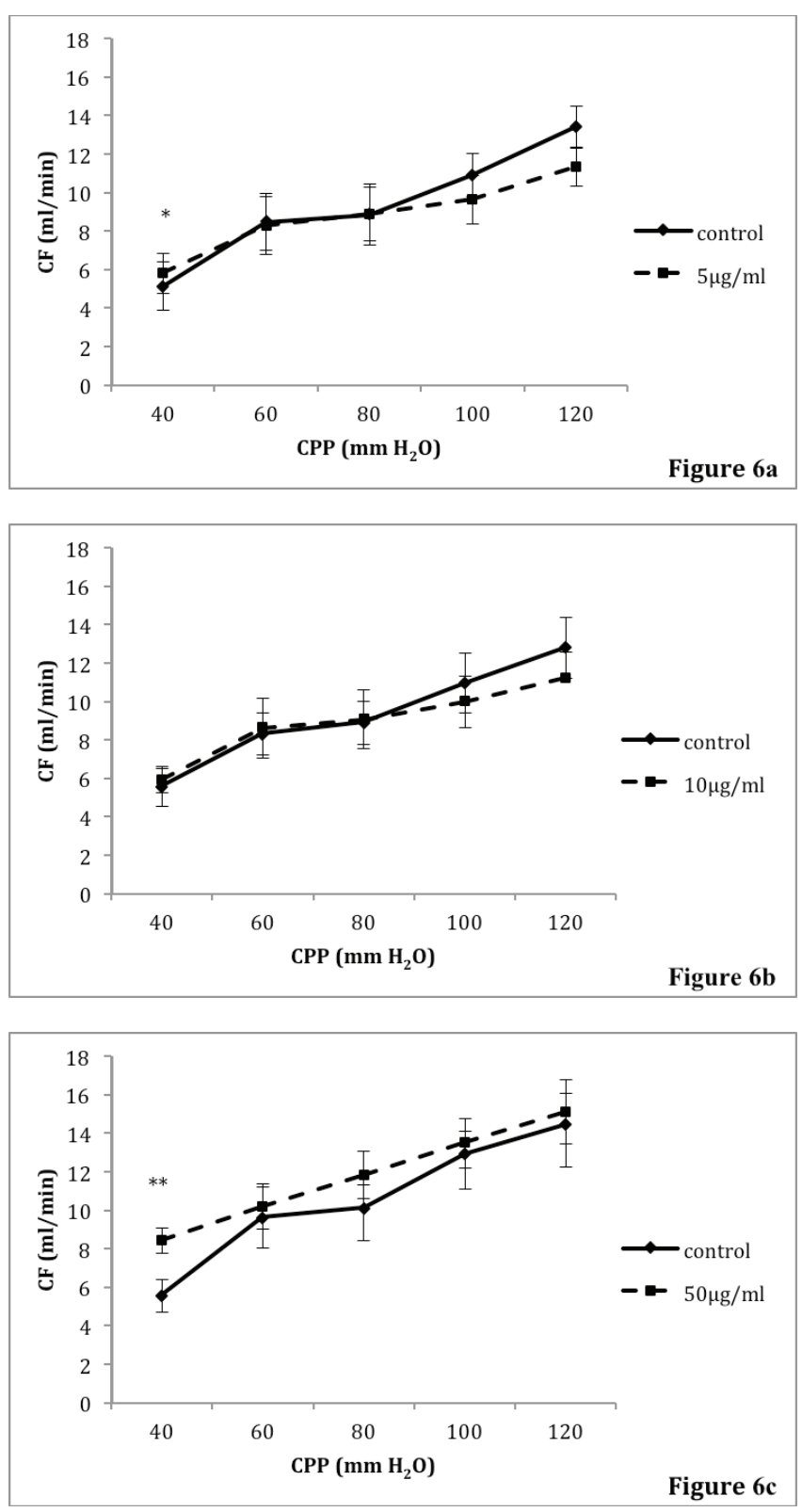

Figure 6a-c. The effects of $5 \mu \mathrm{g} / \mathrm{ml}$ provinol (6a), $10 \mu \mathrm{g} / \mathrm{ml}$ provinol (6b) and $50 \mu \mathrm{g} / \mathrm{ml}$ provinol (6c) on CF. The values represent $\mathrm{X} \pm \mathrm{SE}$; " $\mathrm{p}<0.05$, **\% $<0.01$.

onary flow was increased in the $50 \mu \mathrm{g} / \mathrm{ml}$ group at $\mathrm{CPP}=$ $40 \mathrm{cmH}_{2} \mathrm{O}(\mathrm{p}<0,01)$ (Figure 6c).

\section{DISCUSSION}

As previously noted, red wine polyphenols have been reported to possess beneficial properties for the prevention of cardiovascular diseases $(13,19)$, but the molecular mechanisms underlying their haemodynamic effects on the cardiovascular and renal systems are much more poorly understood (19). Polyphenolic compounds have been documented to relax precontracted smooth muscle of arteries with an intact endothelium. Moreover, some of these compounds were shown to relax endothelium-denuded ar- 
teries $(20,21)$. Another therapeutically relevant effect of flavonoids may be their ability to interact with the generation of NO from the vascular endothelium, which leads not only to vasodilatation but also to the expression of genes that protect the cardiovascular system (22-24). Provinols have been shown to improve human endothelial vascular function (25) and reduce blood pressure in animal studies $(16,17,19)$, but the results of human intervention studies investigating the effect of red wine polyphenols on blood pressure are inconsistent.

The aim of the present study was to assess the influence of acute administration of provinols on cardiac function and coronary flow in the isolated rat heart.

Cardiac contractility was estimated according to the maximum and minimum rate of left ventricle pressure development (dp/dt max and $\mathrm{dp} / \mathrm{dt} \min )$. The first parameter $(\mathrm{dp} / \mathrm{dt} \max )$ represents an indirect indicator of the contractile force of the myocardium (inotropic properties), while $\mathrm{dp} / \mathrm{dt}$ min reflects the ability of the cardiac muscle to relax during diastole (lusitropic properties). The lowest dose of provinols did not induce any significant changes in the contractile force of the myocardium (dp/dt max), while the intermediate and the highest doses increased the values of this marker (at $\mathrm{CPP}=40 \mathrm{cmHg}$ ) (Figs 1b, 1c). Another parameter related to contractility (dp/dt min) showed the same trend of reactivity (Figs $2 \mathrm{a}-\mathrm{c}$ ). Furthermore, our results revealed a decrease in SLVP (Figs 3a-c) and DLVP (Figs 4a, 4b, 4c) following the acute administration of provinols at all tested doses. Using the similar study model, Ferrara and coauthors examined the effects of freeze-dried red wine (FDRW) on cardiac function and ECG in Langendorffperfused rat hearts. These authors noted reduced left ventricular pressures, but at a 10 percent higher concentration in comparison with our highest dose (26). However, FDRW has a different content of polyphenols then red wine extracts produced without using a freezedrying technique.

For HR, the results of present study showed that the highest dose of provinols induced an increase of HR, while the other doses did not significantly change this parameter (Figs 5a, 5b). Dillenburg and colleagues recently investigated the effects of the red wine polyphenol resveratrol on HR and other haemodynamic parameters in hypertensive rats. Their results indicated that resveratrol did not alter HR values in these rats (16). Differences between this previous study and the present study regarding the different experimental models used may be a likely explanation for the obtained results. On the contrary, human studies have documented that daily consumption of red wine (40 grams) for 4 weeks results in an increased 24-hour systolic HR in normotensive humans (27). Based on all of the above results, it seems that red wine may alter HR predominantly in the absence of hypertensive conditions.

The data describing the potential mechanism underlying the effects of polyphenols on the heart are still insufficient. Studies on the effects of the red grape polyphenols quercetin, catechin and resveratrol on cardiac voltagegated sodium channels (VGSCs) suggest that some of their cardioprotective effects may involve inhibition of the $\mathrm{Na}^{+}$current (28). This protective mechanism involves improved myocyte calcium handling and contractility, downstream of the inhibition of the late $\mathrm{Na}^{+}$current.

On the other hand, the influence of red wine extracts on the coronary endothelium are less well understood. CF was increased after the administration of the lowest and highest doses of provinols tested in this work (Figs 6a, 6c), as shown by Shimada et al., who investigated the effects of red wine in healthy volunteers (29). The positive effects of polyphenols on the coronary endothelium could be related to a reduced oxidant status and increased production of $\mathrm{NO}$, as indicated by the increase in NO synthase activity in both cardiac and aortic tissues $(13,17,19)$. Such enhanced NO production could contribute to the relaxation of vascular smooth muscles and the increase in CF induced by provinols.

\section{CONCLUSIONS}

Generally viewed, the results of the present study suggest that provinols may have a beneficial effect on the intact myocardium and coronary circulation. These findings could be an important step in further investigation of these polyphenols under different representative experimental conditions in the heart (ischaemic/reperfusion injury), as well as providing a good basis for potential clinical studies in this field.

\section{Acknowledgements}

This work was supported by the Faculty of Medical Sciences, University of Kragujevac (Junior Project 04/11).

\section{Disclosures}

The authors declare that they have no conflicts of interests relevant to the manuscript.

\section{REFERENCES}

1. Seruga M, Novak I, Jakobek L. Determination of polyphenols content and antioxidant activity of some red wines by differential pulse voltammetry, HPLC and spectrophotometric methods. Food Chem. 2011; 124: 1208-16.

2. Renaud S, De Lorgeril M. Wine, alcohol, platelets, and the French paradox for coronary heart disease. The Lancet. 1992; 339(8808): 1523-6.

3. Hennekens CH, Willett W, Rosner B, et al. Effects of beer, wine and liquor in coronary death. JAMA. 1979; 242: 1973-4.

4. Rimm EB, Giovannucci E, Willet WC, et al. Alcohol and mortality. Lancet. 1991; 338: $1073-4$. 
5. De Whalley CV, Rankin SM, Hoult JR, Jessup W, Leake DS. Flavonoids inhibit the oxidative modification of low density lipoproteins by macrophages. BiochemPharmacol. 1990; 39: 1743 -50.

6. Teissedre PL, Frankel EN, Waterhouse AL, et a1. Inhibition of in vitro human LDL oxidation by phenolic antioxidants from grapes and wines. Sci Food Agric. 1996; 70: 55 - 61.

7. Lavy A, Puhrman B, Markel A, et al. Effect of dietary supplementation of red or white wine on human blood chemistry, hematology and coagulation: favourable effect of red wine on plasma high-density lipoprotein. Ann NutrMetab. 1994; 38 (5) 287 - 94.

8. Martin S, Andriambeloson E, Takeda K, Andriantsitohaina R. Red wine polyphenols increase calcium in bovine aortic endothelial cells: a basis to elucidate signaling pathways leading to nitric oxide production. British journal of pharmacology. 2002; 135(6): 1579-87.

9. Hertog MGL, Feskens EJM, Hollman PCH, Katan MB, Kroumhout D. Dietary antioxidant flavonoids and risk of coronary heart disease: the Zupthen Elderly Study. Lancet. 1993; 342: 1007-11.

10. Keli SO, Hertog MGL, Feskens EJM, Kroumhout D. Flavonoids, antioxidant vitamins and risk of stroke. The Zupten Study. Arch Intern Med. 1996; 156: 637-42.

11. He S, Sun C, Pan Y. Red wine polyphenols for cancer prevention. Int J Mol Sci. 2008; 9(5): 842-53.

12. Pietta P, Simonetti P, Gordana C, Brusamolino A, Morazzoni P, Bombardelli E. Relationship between rate and extent of catechin absorption and plasma antioxidant status. BiochemMolBiol Int. 1998; 46: 895- 903.

13. Pechanova O, Bernátová I, Babál P, et al. Red wine polyphenols prevent cardiovascular alterations in L-NAMEinduced hypertension. J Hypertens.2004; 22(8): 1551-9.

14. Pal S, Ho N, Santos C, et al. Wine Polyphenolics Increase LDL Receptor Expression and Activity and Suppress the Secretion of ApoB100 from Human Hep G2 Cells. Nutr. 2003; 133 (3): 700-6.

15. Zenebe W, Pechánová $\mathrm{O}$, Andriantsitohaina R. Red wine polyphenols induce vasorelaxation by increased nitric oxide bioactivity. Physiol Res. 2003; 52(4): 425-32.

16. Dillenburg DR, Mostarda C, Moraes-Silva IC, et al. Resveratrol and grape juice differentially ameliorate cardiovascular autonomic modulation in L-NAMEtreated rats. Auton Neurosci. 2013; 179(1-2): 9-13.
17. Bernátová I, Pechánová O, Babál P, Kyselá S, Stvrtina $\mathrm{S}$, Andriantsitohaina R. Wine polyphenols improve cardiovascular remodeling and vascular function in NO-deficient hypertension. Am J Physiol Heart Circ Physiol. 2002; 282(3): H942-8.

18. Fitzpatrick DF, Hirschfield SL, Coffey RG. Endotheliumdependent vasorelaxing activity of wine and other grape products.Am J Physiol. 1993; 265 (2 Pt 2): H774-8.

19. Pecháňová O, Rezzani R, Babál P, Bernátová I, Andriantsitohaina R. Beneficial Effects of Provinols ${ }^{\mathrm{Tm}}$ : Cardiovascular System and Kidney. Physiol. Res. 2006; 55 (1): S17-S30.

20. Fuster V, Badimon L, Badimon JJ, Chesebro JH. The patogenesis of coronary artery disease and the acute coronary syndromes. New Engl J Med. 1992; 326: 242-50.

21. Andriambelson E, Kleschyov A, Muller B, Beretz A, Stoclet JC, Andriantsitohaina R. Nitric oxide production and endothelium-dependent vasorelaxation induced by wine polyphenols in rat thoracic aorta. Br J Pharmacol. 1997; 120: 1053-8.

22. Middleton EJR, Kandaswami C, Theoharides TC. The effect of plant flavonoids on mammalian cells: Implications for inflammation, heart disease and cancer. Pharmacol Rev. 2000; 52: 673-751.

23. Zenebe W, Pecháňová O. Effects of red wine polyphenolic compounds on the cardiovascular system. BratislLekListy. 2002; 103: 159-65.

24. Curin Y, Andriantsitohaina R. Polyphenols as potential therapeutical agents against cardiovascular diseases. Pharmacol Rep. 2005; 57: 97-107.

25. Perez-Vizcaino F, Duarte J, Andriantsitohaina R. Endothelial function and cardiovascular disease: effects of quercetin and wine polyphenols. Free radical research. 2006; 40(10): 1054-65.

26. Ferrara A, Fusi F, Gorelli B, Sgaragli G, Saponara S. Effects of freeze-dried red wine on cardiac function and ECG of the Langendorff-perfused rat heart. Can J Physiol Pharmacol. 2014; 92(2): 171-4.

27. Zilkens RR, Burke V, Hodgson JM, Barden A, Beilin LJ, Puddey IB. Red wine and beer elevate blood pressure in normotensive men. Hypertension. 2005; 45(5): 874-9.

28. Wallace CH, Baczkó I, Jones L, Fercho M, Light PE. Inhibition of cardiac voltage-gated sodium channels by grape polyphenols. Br J Pharmacol. 2006; 149(6): 657-65.

29. Shimada K, Watanabe H, Hosoda K, Takeuchi K, Yoshikawa J. Effect of red wine on coronary flow-velocity reserve. Lancet 1999; 354:1002. 


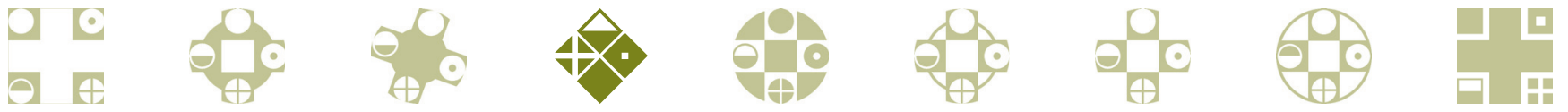

